\title{
Vitamin K Status and Bone Mass in Women With and Without Aortic Atherosclerosis: A Population-Based Study
}

\author{
K.-S. G. Jie, ${ }^{1}$ M. L. Bots, ${ }^{2}$ C. Vermeer, ${ }^{1}$ J. C. M. Witteman, ${ }^{2}$ D. E. Grobbee ${ }^{2}$ \\ ${ }^{1}$ Department of Biochemistry and Cardiovascular Research Institute Maastricht (CARIM), University of Limburg, P.O. Box 616, 6200 MD \\ Maastricht, The Netherlands \\ ${ }^{2}$ Department of Epidemiology \& Biostatistics, and Cardiovascular Research Institute Rotterdam (COEUR), Erasmus University Medical School, \\ Rotterdam, The Netherlands
}

Received: 15 January 1996 / Accepted: 3 May 1996

\begin{abstract}
Gammacarboxyglutamate (Gla) is an uncommon amino acid formed by vitamin $\mathrm{K}$ action. Increasing evidence indicates that Gla-proteins are involved in the regulation of calcification processes in both bone tissue and atherosclerotic vessel wall. In a population-based study we have previously shown that in a group of 113 postmenopausal women the presence of abdominal aortic calcifications is associated with a reduced vitamin $\mathrm{K}$ status. In the present study we investigated whether this reduced vitamin K status was also associated with differences in bone mass or circulating calciotropic hormone levels. Serum immunoreactive osteocalcin with low affinity for hydroxyapatite $\left(\mathrm{irOC}_{\text {free }}\right)$ was used as a marker for vitamin K status. After correction for age it was found that women with atherosclerotic calcifications had a 7\% lower bone mass as measured by metacarpal radiogrammetry (mean difference: $3.2 \mathrm{~mm}^{2}$, $95 \% \mathrm{CI}$ : $-0.2-6.5, P=0.06$ ). No differences between both groups of women were observed for serum intact parathyroid hormone (PTH) and serum 25-hydroxyvitamin D levels. In the atherosclerotic women $(\mathrm{n}=34)$, markers for vitamin $\mathrm{K}$ status were inversely associated with bone mass $(\mathrm{r}=-0.47$, $P=0.013$ ), whereas no such association was found in the nonatherosclerotic women $(\mathrm{n}=79)$. It is concluded that the atherosclerotic women in this study may be at higher risk for osteoporotic fractures as evidenced by their lower bone mass and higher serum irOC ${ }_{\text {free }}$ levels. The finding that in atherosclerotic women vitamin $\mathrm{K}$ status is associated with bone mass supports our hypothesis that vitamin $\mathrm{K}$ status affects the mineralization processes in both bone and in atherosclerotic plaques.
\end{abstract}

Key words: Vitamin $\mathrm{K}$ - Gammacarboxyglutamate - Osteocalcin - Calcification - Atherosclerosis - Bone mass.

Osteoporosis and atherosclerosis are two major chronic causes of morbidity. Although they tend to be regarded as two independent, age-related processes, it is striking that in women the prevalence of both disorders increases dramatically after menopause [1]. Estrogen deficiency or a derangement in calcium metabolism have been proposed as candidates for common pathophysiological factors [2-4].

Results from recent studies suggest that atherosclerotic

Correspondence to: C. Vermeer calcification must be regarded as a highly regulated process similar to that occurring in bone tissue [5]. It is of interest that in both calcification processes vitamin K-dependent proteins are thought to be involved [6-9]. Vitamin Kdependent proteins have calcium-binding properties mediated by the posttranslationally acquired $\gamma$-carboxyglutamate (Gla) residues [10]. A diminished availability of vitamin K, e.g., due to a reduced nutritional intake or impaired intestinal absorption, may result in a decreased Gla-content of the various Gla-proteins. In the latter case, Gla-proteins, such as osteocalcin, will be functionally defective resulting in a reduced affinity for the hydroxyapatite bone matrix. This can be measured in serum as the serum immunoreactive osteocalcin with a low affinity for hydroxyapatite $\left(\mathrm{irOC}_{\text {free }}\right)$ [11]. The high affinity osteocalcin (irOC $\mathrm{bound}_{\text {) }}$ ), expressed as a percentage of total serum osteocalcin, is called the hydroxyapatite-binding capacity of osteocalcin (HBC) and is regarded as a measure for osteocalcin Glacontent and for vitamin K status [12-14]. Since the correlation between circulating vitamin $\mathrm{K}$ and tissue vitamin $\mathrm{K}$ is unclear at this time, undercarboxylated Gla-proteins form a unique tool to assess the vitamin $\mathrm{K}$ status in the tissues from which these proteins originate.

It has been suggested that even a mild vitamin $\mathrm{K}$ deficiency may affect calcium homeostasis. In a number of trials, we have recently shown that markers of bone formation increase, whereas bone resorption markers decrease with the administration of pharmacological doses of vitamin $\mathrm{K}$ [12-14]. These data are consistent with two Japanese studies, both of which demonstrated that vitamin K supplementation may retard postmenopausal loss of bone mass $[15,16]$. We have recently shown that in a group of postmenopausal women, the presence of atherosclerotic calcifications in the abdominal aorta, considered to be a strong predictor of cardiovascular heart disease and mortality [1719], is associated with a marginal vitamin $\mathrm{K}$ status [20]. In the present study we examined whether the reduced vitamin $\mathrm{K}$ status in the atherosclerotic women was associated with a reduced bone mass as well.

\section{Materials and Methods}

Subjects

Participants were selected from a population-based study on determinants of osteoporosis and atherosclerosis [21]. Bone mass 
Table 1. Parameters tested in postmenopausal women with and without calcifications of the abdominal aorta

\begin{tabular}{|c|c|c|c|c|c|c|}
\hline & \multicolumn{2}{|c|}{ Aortic calcifications } & \multirow[b]{2}{*}{ Mean difference } & \multirow[b]{2}{*}{$P$-value } & \multirow[b]{2}{*}{ Age adj. difference } & \multirow[b]{2}{*}{$P$-value } \\
\hline & Absent & Present & & & & \\
\hline Number & 79 & 34 & & & & \\
\hline $\operatorname{irOC}_{\text {free }}(\mathrm{ng} / \mathrm{ml})$ & $1.93(0.08)$ & $2.16(0.15)$ & $0.23[-0.07,0.53]$ & 0.14 & $0.32[0.03,0.61]$ & 0.04 \\
\hline $\operatorname{HBC}(\%)$ & $59.4(0.98)$ & $54.6(1.77)$ & $-4.79[-8.49,-1.09]$ & 0.01 & $-5.12[-8.92,-1.32]$ & 0.01 \\
\hline Bone mass $\left(\mathrm{mm}^{2}\right)$ & $45.1(0.9)$ & $41.6(1.4)$ & $-3.5[-6.7,-0.2]$ & 0.04 & $-3.2[-6.5,0.2]$ & 0.06 \\
\hline iPTH (pg/ml) & $41.6(1.8)$ & $43.7(2.8)$ & $2.1[-4.2,8.4]$ & 0.52 & $2.0[-4.4,8.5]$ & 0.54 \\
\hline $25 \mathrm{OHD}(\mathrm{ng} / \mathrm{ml})$ & $15.4(1.6)$ & $16.8(1.6)$ & $1.4[-3.1,5.8]$ & 0.07 & $1.8[-2.5,6.2]$ & 0.41 \\
\hline
\end{tabular}

Values are given as means with standard errors. (in parentheses) and 95\% confidence intervals [in brackets]

Abbreviations: irOCfree = serum immunoreactive osteocalcin free; HBC = hydroxyapatite-binding capacity of serum osteocalcin; iPTH $=$ intact serum PTH; 250HD = serum 25-hydroxyvitamin D

measurements as well as the extent of calcified deposits in the abdominal aorta were determined in 1985. In 1990, 256 women consented to take part in a follow-up examination [20]. In brief, aortic calcification (grade 3 or grade 4 ) was found to be present in 34 subjects. Seventy-nine women without aortic calcification (grade 0) were randomly selected from the cohort. Subjects using vitamin $\mathrm{K}$ antagonists were excluded.

\section{Abdominal Aorta Calcification}

Atherosclerosis of the abdominal aorta was assessed using a lateral $\mathrm{X}$-ray film of the lumbar spine (T12-S1), from which the presence of calcified deposits was determined [22]. The severity of the atherosclerosis was graded from 0 (no calcifications) to 4 (aorta outlined with calcifications) [20].

\section{Bone Mass}

Bone mass measurements was determined using metacarpal radiogrammetry. The outer diameter (D) and medullar diameter (d) were measured at the midshaft of the metacarpal bones, using a 7 times magnifying measurement loop with an accuracy of $0.01 \mathrm{~mm}$. Bone mass (metacarpal cortical area) was expressed as the mean value of $\mathrm{D}^{2}-\mathrm{d}^{2}\left(\mathrm{~mm}^{2}\right)$ of the metacarpal bones II, III, and IV of both hands. The mean intra-individual standard deviation (SD) of a duplicate measurement was $1.9 \mathrm{~mm}^{2}(4 \%)$, which is in accordance with previous reports [23].

\section{Anthropometric Variables}

Height and weight were measured without shoes and with indoor clothing. The body mass index $\left(\mathrm{kg} / \mathrm{m}^{2}, \mathrm{BMI}\right)$ was calculated. The circumferences of the waist and hip were measured and the waistto-hip ratio (WH-ratio) was calculated.

\section{Vitamin K Status}

Immediately after preparation, the nonfasting serum and plasma samples were frozen at $-80^{\circ} \mathrm{C}$. Serum immunoreactive osteocalcin (irOC) levels were measured before (irOC $\mathrm{total}$ ) and after ( $\mathrm{irOC}_{\text {free }}$ ) extraction with $100 \mathrm{mg} / \mathrm{ml}$ hydroxyapatite [12]. Serum irOC ${ }_{\text {bound }}$ was calculated from the difference between irOC ${ }_{\text {total }}$ and irOC ${ }_{\text {free }}$. The HBC was calculated as the percentage of irOC $_{\text {bound }}$ relative to the total serum irOC level and used as an overall estimate of the Gla-content of circulating irOC levels. In young, healthy adults, the $\mathrm{HBC}$ values range between 70 and $80 \%$; decreased values are found in subjects with a marginal vitamin $\mathrm{K}$ status $[12,13]$. Interand intraassay coefficients of variation of serum irOC $\mathrm{ital}_{\text {tal }}$ were $10 \%$ and $5 \%$, respectively.

\section{Additional Measurements}

Serum intact parathyroid hormone levels (iPTH) were measured with a direct immunoradiometric assay (IRMA) (N-tact $\left.{ }^{\circledR}\right)$ PTH $\mathrm{SP}$ ) and serum 25-hydroxyvitamin D (250HD) levels were determined using radioimmunoassay (RIA) (both obtained from Incstar, Stillwater, MI).

\section{Data Analysis}

Multiple linear regression was used for analysis of differences across groups with and without atherosclerosis, adjusted for confounding variables such as age. The differences are presented with a $95 \%$ confidence interval (95\% CI). Analyses were performed using the BMDP statistical package. Results are presented as the mean values $( \pm$ SD) unless indicated otherwise.

\section{Results}

As reported previously, no major differences were noted between the women with or without atherosclerosis with respect to their age $(67.8 \pm 5.5$ and $66.1 \pm 4.1$, respectively), BMI $25.4 \pm 3.2$ and $26.5 \pm 3.0 \mathrm{~kg} / \mathrm{m}^{2}$, respectively), or WH-ratio (0.84 \pm 0.05 and $0.84 \pm 0.06$, respectively) [20]. The atherosclerotic women had higher serum total cholesterol levels $(7.56 \pm 1.05 \mathrm{mmol} / \mathrm{liter})$ compared with the nonatherosclerotic women $(6.85 \pm 1.00 \mathrm{mmol} / \mathrm{liter}, P<$ $0.01)$, whereas no difference was noted in their serum HDLcholesterol levels $(1.84 \pm 0.65$ and $1.74 \pm 0.94 \mathrm{mmol} / \mathrm{liter}$, respectively).

The bone mass of the atherosclerotic and nonatherosclerotic women was 41.6 and $45.1 \mathrm{~mm}^{2}$, respectively, constituting a mean difference of $3.5 \mathrm{~mm}^{2}(95 \% \mathrm{CI}:-6.7,-0.2)$ or $8 \%(P=0.04)$ (Table 1$)$. Adjustment for age slightly attenuated the difference to $-3.2 \mathrm{~mm}^{2}(95 \% \mathrm{CI}:-6.5,0.2 P=$ 0.06). In the atherosclerotic women, bone mass was significantly associated with both serum irOC ${ }_{\text {free }}(\mathrm{r}=-0.47, P=$ 0.013 ) and HBC levels ( $\mathrm{r}=0.57, P=0.002)$ (Table 2). No such associations were found in the women without atherosclerosis (Table 2). Adjustment for age, BMI, or serum cholesterol did not essentially alter these findings (data not shown).

No differences were observed in serum iPTH and 250HD levels (Table 1). Serum 250HD levels of $12 \mathrm{ng} / \mathrm{liter}$ (considered as borderline value) and lower were present in $44 \%$ of the women $[24,25]$. In both the atherosclerotic and nonatherosclerotic women, bone mass was positively associated with serum 250HD levels (pooled data: $\mathrm{r}=0.23, P$ 
Table 2. Correlations tested in postmenopausal women with and without calcifications of the abdominal aorta

\begin{tabular}{|c|c|c|c|c|c|c|}
\hline \multirow[b]{2}{*}{ Correlations tested } & \multicolumn{2}{|c|}{ Aortic calcif. absent } & \multicolumn{2}{|c|}{ Aortic calcif. present } & \multicolumn{2}{|c|}{ Pooled data } \\
\hline & $\mathrm{r}$ & ( $p$-value) & $\mathrm{r}$ & ( $p$-value) & $\mathrm{r}$ & ( $p$-value) \\
\hline Bone mass - irOC free $_{\text {fre }}$ & 0.12 & $(0.33)$ & -0.47 & $(0.013)$ & & \\
\hline Bone mass - HBC & -0.14 & $(0.28)$ & 0.57 & $(0.002)$ & & \\
\hline Bone mass - 25OHD & & & & & 0.23 & $(0.07)$ \\
\hline Bone mass - iPTH & & & & & 0.10 & $(0.36)$ \\
\hline $\mathrm{iPTH}-\mathrm{irOC}_{\text {free }}$ & 0.30 & $(0.01)$ & 0.39 & $(0.03)$ & 0.30 & $(0.002)$ \\
\hline iPTH - HBC & -0.27 & $(0.02)$ & -0.21 & $(0.05)$ & -0.27 & $(0.005)$ \\
\hline
\end{tabular}

Abbreviations: $r=$ correlation coefficient. For other abbreviations see Table 1; where correlations were ommitted, no significance was observed

$=0.07$ ), but not with serum iPTH (pooled data: $\mathrm{r}=0.10$, $P=0.36$ ) (Table 2). Serum iPTH levels were significantly associated with serum irOC ${ }_{\text {free }}$ (pooled data: $\mathrm{r}=0.30, P=$ 0.002 ) and HBC (pooled data: $\mathrm{r}=-0.27, P=0.005$ ) levels in both groups. The associations remained essentially unchanged after additional adjustments for possible confounders as age, BMI, and serum cholesterol levels.

\section{Discussion}

The results of our study indicate that in postmenopausal women the presence of atherosclerotic calcifications in the abdominal aorta is not only associated with a marginal vitamin K status [20], but also with a low bone mass. In comparisons of necropsy with computed tomography findings, atherosclerotic calcifications in the abdominal aorta have previously been shown to represent severe aortic atherosclerosis [26, 27]. These calcifications have shown to be strong predictors of coronary heart disease [28, 29] and cardiovascular mortality $[18,19,28]$. Assessment of bone mass by radiogrammetry based on multiple measurements of six metacarpal bones, on the other hand, has been shown to be sufficiently precise for meaningful comparisons of bone density between individuals [21,23].

Low bone mass is a well established and important risk factor for the development of osteoporotic fractures [30, $31]$. Recent data strongly indicate that high serum $\mathrm{irOC}_{\text {free }}$ levels are associated with an increased risk for hip fractures [32] and that in elderly women, elevated serum $\mathrm{iOC}_{\text {free }}$ levels are associated with a low bone mass [33]. The findings of our study that atherosclerotic women had a low bone mass and high irOC ${ }_{\text {free }}$ levels therefore strongly suggest that they are at increased risk for developing osteoporotic fractures.

Several studies have reported that both low bone mass and increased frequency of osteoporotic fractures are associated with atherosclerotic calcifications [2, 3, 34-37] or cardiovascular deaths $[4,38]$. Some have regarded the observed associations merely as being age-related phenomena $[35,36]$, whereas others have suggested a causal relationship [2, 3, 34, 38]. High serum levels of iPTH or 250HD have been proposed as causally related factors, however, this is not supported by our data. The $250 \mathrm{HD}$ and $\mathrm{iPTH}$ serum levels in our study are in accordance with other studies performed in The Netherlands [24, 25]. The relatively high serum iPTH levels in our study population are indicative of a secondary hyperparathyroidism commonly found in women of this age $[25,39]$. The finding that serum iPTH is associated with serum irOC $_{\text {free }}$ levels suggests that serum

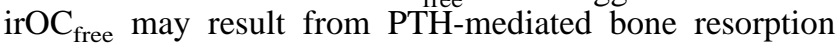
[40]. Although it is assumed that serum irOC $\mathrm{Cree}_{\text {free }}$ consists of undercarboxylated osteocalcin, there is some evidence that at least part of the circulating $\operatorname{irOC}_{\text {free }}$ is formed by denatured osteocalcin or osteocalcin degradation products, possibly originating from bone resorption [14, 40].

Accumulating evidence suggests that vitamin $\mathrm{K}$ stimulates bone formation and inhibits bone resorption which ultimately may lead to a decrease in bone loss [12-16]. The fact that only in the atherosclerotic women both markers for vitamin $\mathrm{K}$ status were strongly associated with bone mass suggests that additional (as yet unknown) factors may be of importance. It has been suggested for instance that abnormalities in lipoprotein metabolisms may influence vitamin $\mathrm{K}$ transport to bone tissue [41].

The question remains What may be the pathophysiological mechanism in which a reduced vitamin $\mathrm{K}$ status leads to a lower bone and an increased frequency of atherosclerotic calcifications. Recent evidence strongly supports the concept that the calcification associated with atherosclerosis must be regarded as an active, highly organized process similar to that of osteogenesis [5, 42]. Gla-proteins appear to be involved in both processes $[6,8,9]$. The Gla-proteins MGP (matrix Gla-protein) and osteocalcin are both involved in the bone mineralization process. Their exact function, however, is still unclear. Recently, high levels of MGP mRNA and protein were demonstrated in macrophages and in vascular smooth muscle cells, present in human atherosclerotic plaques [9]. This strongly suggests that MGP found in the plaques is not absorbed from the blood stream, but that it is produced locally at the site of these plaques. We speculate that the function of vascular MGP is similar to that in bone [43], i.e., that it acts as a mineralization inhibitor. By analogy with the fetal warfarin syndrome [44], undercarboxylation of MGP would thus be a risk factor for excessive mineralization of the atherosclerotic vessel wall. Osteocalcin, on the other hand, is predominantly synthesized by the more differentiated osteoblast, relatively late in bone development, concomitant with or after the onset of mineralization [45]. Also, its different molecular properties and tight association with the mineral matrix suggest a different function for osteocalcin, for instance, in bone remodeling or in the accumulation of bone mass [46]. In mature bone tissue, a suboptimal vitamin $\mathrm{K}$ status might thus affect the osteocalcin-mediated remodeling process ultimately leading to a net loss of bone mass [12-16].

In conclusion, we found that the presence of atherosclerotic calcifications in postmenopausal women is associated 
with an impaired vitamin $\mathrm{K}$ status as well as a low bone mass. These findings support the view that aortic calcification and bone loss may be two related processes, with vitamin K deficiency as a common denominator. Further studies are needed to investigate the potential benefit of vitamin K supplementation.

Acknowledgment. The authors gratefully acknowledge the contribution of Hanneke den Breeijen, MSc and Helen de Bruin for their help in collecting the data.

\section{References}

1. Stevenson JC (1990) Osteoporosis and cardiovascular disease in women: converging path? Lancet 336:1121-1122

2. Orimo H, Terashita K, Nakamura T, Ohshima J (1985) Ca and atherosclerosis. J Nutr Sci Vitaminol 31(suppl):S33-S36

3. Fujita T, Okamoto Y, Sakagami Y, Kiichiro O, Ohata M, (1984) Bone changes and aortic calcification in aging inhabitants of mountain versus seacoast communities in the Kii peninsula. J Am Soc Geriatric Soc 32:124-128

4. Browner WS, Seeley DG, Vogt TM, Cummings SR (1991) Non-trauma mortality in elderly women with low bone mineral density. Lancet 338:335-338

5. Demer LL, Watson KE, Boström K (1994) Mechanism of calcification in atherosclerosis. Trends Cardiovasc Med 4:4549

6. Price PA, Otsuka AS, Poser JW, Kristaponis J, Raman N (1976) Characterization of a gammacarboxyglutamic acidcontaining protein form bone. Proc Natl Acad Sci USA 73: 1447-1451

7. Gallop PM, Lian JB, Hauschka PV (1980) Carboxylated calcium-binding proteins and vitamin K. N Engl J Med 302: 1460-1466

8. Levy RJ, Gundberg C, Scheinman R (1983) The identification of the vitamin K-dependent bone protein osteocalcin as one of the $\gamma$-carboxyglutamatic acids containing proteins present in calcified atherosclerotic plaque and mineralized heart valves. Atherosclerosis 46:49-56

9. Shanahan CM, Cary NRB, Metcalfe JC, Weissberg PL (1994) High expression of genes for calcification-regulation proteins in human atherosclerotic plaques. J Clin Invest 93:2393-2402

10. Vermeer C (1990) Gamma-carboxyglutamate-containing proteins and the vitamin K-dependent carboxylase. Biochem J 266:625-636

11. Price PA, Williamson MK, Lothringer JW (1981) Origin of the vitamin K-dependent bone protein found in plasma and its clearance by kidney and bone. J Biol Chem 256:12760-12766

12. Knapen MHJ, Hamulyák K, Vermeer C (1989) The effect of vitamin $\mathrm{K}$ supplementation on circulating osteocalcin (bone Gla-protein) and urinary calcium excretion. Ann Int Med 111: 1001-1005

13. Jie K-SG, Gijsbers BLMG, Knapen MHJ, Hamulyák K, Frank HL, Vermeer C (1993) Effects of vitamin K and oral anticoagulants on urinary calcium excretion. Br J Haematol 83:100104

14. Knapen MHJ, Jie K-SG, Hamulyák K, Vermeer C (1993) Vitamin K-induced changes in markers for osteoblast activity and urinary calcium loss. Calcif Tissue Int 53:81-85

15. Akiba T, Kurihara S, Tachibana K, Kuwahara M, Sakamoto H, Yoneshima H, Marumo F (1991) Vitamin K increased bone mass in hemodialysis patients with low-turnover bone disease. J Am Soc Nephrol 2:608

16. Orimo H, Shiraki M, Fujita T, Onomura T, Inoue T, Kushida K (1992) Clinical evaluation of menatetrenone in the treatment of involutional osteoporosis - a double-blind multicenter comparative study with $1 \alpha$ hydroxy vitamin $\mathrm{D}_{3}$. J Bone Miner Res 7:S122

17. Witteman JCM, Grobbee DE, Kok FJ, Hofman A, Valkenburg
HA (1989) Increased risk of atherosclerosis in women after the menopause. Br Med J 298:642-644

18. Witteman JCM, Kok FJ, van Saase JLCM, Valkenburg HA (1986) Aortic calcification as a predictor of cardiovascular mortality. Lancet ii:1120-1122

19. Eggen DA (1968) Relationship of calcified lesions to clinically significant atherosclerotic lesions. Ann NY Acad Sci 149:752-767

20. Jie K-SG, Bots ML, Vermeer C, Witteman JCM, Grobbee DE (1995) Vitamin K intake and osteocalcin levels in women with and without aortic atherosclerosis: a population-based study. Atherosclerosis 116:117-123

21. Hoes AW, Grobbee DE, Valdenburg HA, Lubsen J, Hofman A (1993) Cardiovascular risk and all-cause mortality. A twelve-year follow-up study in The Netherlands. Eur J Epidemiol 9:285-292

22. Witteman JCM, Grobbee DE, Valkenburg HA, van Hemert AM, Stijnen T, Hofman A (1993) Cigarette smoking and the development and progression of aortic atherosclerosis. A 9 -year population-based follow-up study in women. Circulation 88:2156-2162

23. Johnston CC Jr (1983) Noninvasive methods for quantitating appendicular bone mass. In: Avioli LV (ed) The osteoporotic syndrome. Orlando, Florida, Grune \& Stratton, pp 73-84

24. Löwik MRH, Schrijver J, Odink J, van den Berg H, Wedel M, Hermus RJJ (1990) Nutrition and aging: nutritional status of " apparently healthy" elderly. J Am Coll Nutr 9:18-27

25. Ooms ME (1994) Osteoporosis in elderly women [thesis]. Amsterdam, Vrije Universiteit

26. Hyman JB, Epstein JH (1954) A study of the correlation between roentgenographic and post-mortem calcification of the aorta. Am Heart J 47:540

27. Witteman JCM, Grobbee DE, Valkenburg HA, van Hemert AM, Stijnen T, Burger H, Hofman A (1994) J-Shaped relation between change in diastolic blood pressure and progression of aortic atherosclerosis. Lancet 343:504-507

28. Witteman JCM, Kannel WB, Grobbee DE, et al. (1990) Aortic calcification plaques and cardiovascular disease. (The Framingham Study). Am J Cardiol 66:1060-1064

29. Siitonen O, Uusitupa M, Pyörälä K, et al. (1987) Aortic calcifications and their relationship to coronary heart disease and cardiovascular risk factors in patients with newly diagnosed non-insulin-dependent diabetes and in non-diabetic subjects. Cardiology 74:335-339

30. Johnston CC, Longcope C (1990) Premenopausal bone loss, a risk factor for osteoporosis. N Engl J Med 323:1271-1272

31. Wasnich R (1993) Bone mass measurement: prediction of risk. Am J Med 95 (suppl 5A):6S-10S

32. Szulc P, Chapuy M-C, Meunier PJ, Delmas PD (1993) Serum undercarboxylated osteocalcin is a marker of the risk of hip fracture in elderly women. J Clin Invest 91:1769-1774

33. Szulc P, Arlot M, Chapuy M-C, Duboeuf F, Meunier PJ, Delmas PD (1994) Serum undercarboxylated osteocalcin correlates with hip bone mineral density in elderly women. J Bone Miner Res 9:1591-1595

34. Elkeles A (1957) A comparative radiological study of calcified atheroma in males and females over 50 years of age. Lancet ii:714-715

35. Anderson JB, Barnett E, Nordin BEC (1964) The relation between osteoporosis and aortic calcification. Br J Radiol 37: 910-912

36. Frye MA, Melton LJ III, Bryant SC, Fitzpatrick LA, Wahner HW, Schwartz RS, Riggs BL (1992) Osteoporosis and calcification of the aorta. Bone Miner 19:185-194

37. Ouchi Y, Akishita M, de Souza AC, Nakamura T, Orimo H (1993) Age-related loss of bone mass and aortic/aortic valve calcification-reevaluation of recommended dietary allowance of calcium in the elderly. Ann NY Acad Sci 676:297-307

38. Browner WA, Pressman AR, Nevitt MC, Cauley JA, Cummings SR (1993) Association between low bone density and stroke in elderly women. Stroke 24:940-946

39. Compston JE, Silver AC, Croucher PI, Brown RC, Woodhead JS Elevated serum intact parathyroid hormone levels in elderly patients with hip fracture. Clin Endocrinol 31:667-672 
40. Minisola S, Carnevale V, Pacitti MT, Romagnoli E, Scarnecchia L, Rosso R, Minisola G, Mazzuoli GF (1993) Serum osteocalcin in metabolic bone disease: What is its real significance? J Endocrinol Invest 16:277-279

41. Saupe J, Shearer MJ, Kohlmeier M (1993) Phylloquinone transport and its influence on $\gamma$-carboxyglutamate residues of osteocalcin in patients on maintenance hemodialysis. Am J Clin Nutr 58:204-208

42. Watson KE, Boström K, Ravindranath R, Lam T, Norton B, Demer LL (1994) TGF- $\beta 1$ and 25-hydroxycholesterol stimulate osteoblast-like vascular cells to calcify. J Clin Invest 93: 2106-2113
43. Otawara Y, Price PA (1986) Developmental appearance of matrix Gla-protein during calcification in the rat. J Biol Chem 261:10828-1082

44. Pettifor JM, Benson R (1975) Congenital malformations associated with the administration of oral anticoagulants during pregnancy. J Pediatr 86:459-462

45. Price PA, Lothringer JW, Baukol SA, Reddi AH (1981) Developmental appearance of the vitamin K-dependent bone protein during calcification: analysis of mineralizing tissues in human, calf, and rat. J Biol Chem 256:3781-3784

46. Vermeer C, Knapen MHJ, Jie K-SG (1995) Role of vitamin K in bone metabolism. Annu Rev Nutr 15:1-22 